\title{
Lama Kerja Berhubungan dengan Kepatuhan Perawat dalam Pelaksanaan SOP Triage di IGD
}

\author{
Mahfud \\ Universitas Alma Ata, Yogyakarta, Indonesia \\ JI. Brawijaya No. 99 Tamantirto, Kasihan, Bantul, Yogyakarta \\ Email: mahfud@almaata.ac.id
}

\begin{abstract}
Abstrak
Kepatuhan terhadap Standar Operasional Prosedur (SOP) merupakan komponen penting dalam manajemen keselamatan pasien. Dalam Triage diperlukan petugas yang berpengalaman dan kompeten karena dilakukan dengan cepat dan akurat. Jenis penelitian ini deskriptif korelasional dengan pendekatan cross sectional . sampel menggunakan teknik total sampling, instrumen yang digunakan lembar observasi menggunakan metode konstruktif. Mengetahui hubungan lama kerja dengan kepatuhan perawat dalam melaksanakan SOP triage di IGD. Analisa menggunakan uji alternatif yaitu uji fisher exact menunjukkan perawat yang bekerja lama patuh $57,1 \%$ dan yang baru $19 \%$ tidak patuh dan uji fisher exact menunjukan $p=0,120$. Tidak ada hubungan antara lama kerja dengan kepatuhan perawat dalam pelaksanaan SOP triage.
\end{abstract}

Kata Kunci: Lama Kerja, Kepatuhan Perawat, SOP Triage

\section{Relationship Between Length of Work And Nurse Compliance In Implementing Standard Operational Procedures of Triage At IGD}

\begin{abstract}
Compliance with Standard Operating Procedures (SOPS) is an important component in patient safety management. In Triage, experienced and competent officers are needed because they are done quickly and accurately. This type of research is descriptive correlational with a cross sectional approach. the sample uses total sampling technique, the instrument used was the observation sheet using constructive methods. Knowing the long-standing relationship with nurse compliance in implementing SOP triage at the IGD. Analysis using alternative test which is fisher exact test shows nurses with longer experience tend to be more compliant with $57,1 \%$ perform the standard operational procedure. Meanwhile nurses with shorter experience complies with number of $19 \%$. Fisher exact test shows $p=0,120$. There is no relationship between length of work and nurse compliance in implementing standard operational procedures of triage.
\end{abstract}

Keywords: Length of work, nurse compliance, standard operational procedures of triage

Received:29/08/2019; published: 1/10/2019

\section{PENDAHULUAN}

Semakin lama orang bekerja maka kecakapan dan sikap seseorang akan lebih baik karena sudah menyesuaikan diri dengan pekerjaannya (1). Petugas IGD melaksanakan tugasnya berdasarkan standar operasional prosedur (SOP). Kebershasilan petugas IGD sangat tergantung dengan kepatuhan dalam menjalankan SOP. dalam keperawatan meliputi SOP profesi, SOP pelayanan, SOP administrasi. SOP tersebut harus dipatuhi dan dilaksanakan oleh setiap petugas IGD. Dalam pelaksanaannya, petugas IGD harus mampu menggolongkan pasien dengan sistem triage yang ada. Keterampilan triage harus dimiliki oleh setiap petugas. Hal ini dikarenakan, 
dengan adanya kepatuhan maka tingkat risiko kesalahan dalam penanganan pasien dapat terminimalisir (3). Triage adalah proses khusus memilah pasien berdasar beratnya cedera atau penyakit (berdasarkan yang paling mungkinkan mengalami perburukan klinis segera) untuk menentukan prioritas perawatan gawat darurat medik serta prioritas transportasi (berdasarkan ketersediaan sarana untuk tindakan). Tindakan ini berdasarkan prioritas A, B, C, D, E (Airway: jalan nafas, breathing: pernapasan, Circulation: sirkulasi, Disability: ketidakmampuan, Exposure: paparan yang merupakan proses berkesinambungan sepanjang pengelolaan gawat darurat medik (5). Triage dilakukan pada semua pasien yang membutuhkan pelayanan di IGD. Sistem triage pasien yang masuk kriteria true emergency dan false emergency ditentukan dengan tingkat dan derajat kegawatannya dengan menggunakan kriteria emergency severity index (ESI) (6).

Studi pendahuluan yang dilakukan peneliti diperoleh data observasi. Dari 10 orang perawat 6 orang diantaranya bekerja di IGD diatas 5 tahun, kemudian 1 orang bekerja lebih dari 10 tahun di IGD melaksanakan triage sesuai standar operasional prosedur sedangkan 4 orang lainya bekerja kurang dari 5 tahun dan kurang melaksanakan triage sesuai standar operasional prosedur rumah sakit.

\section{BAHAN DAN METODE}

Jenis penelitian ini adalah penelitian kuantitatif menggunakan desain deskriptif corelasional yang bertujuan untuk membuktikan hubungan lama kerja dengan kepatuhan perawat dalam pelaksanaan SOP triage dengan pendekatan cross sectional. Populasi perawat yang bekerja di IGD yang berjumlah 22 orang. Teknik pengambilan sampel secara total sampling. Dengan kriteria perawat yang bersedia menjadi responden dan perawat yang melakukan pelaksanaan triage. Instrumen yang digunakan adalah lembar observasi untuk mengetahui kepatuhan perawat dalam pelaksanaan SOP triage. Instrumen penelitian sudah diuji validitas dan realibilitasnya. Uji instrumennya dengan uji pakar. Dengan hasil $p=0,84$ artinya positif diartikan sebagai memiliki validitas isi atau alat instrument tersebut dapat digunakan untuk penelitian. Analisa data menggunakan uji korelasi fisher exact untuk mengetahui hubungan.

\section{HASIL DAN PEMBAHASAN Karekteristik Responden}

Karekteristik responden berdasarkan umur, Jenis Kelamin, Pendidikan, Lama Kerja, distribusi frekuensi dapat dilihat pada tabel berikut. Penelitian dengan judul ini yaitu Lama Kerja Berhubungan dengan Kepatuhan Perawat dalam Pelaksanaan SOP Triage di IGD. Dalam pelaksanaannya, petugas IGD harus mampu menggolongkan pasien dengan sistem triage yang ada. Keterampilan triage harus dimiliki oleh setiap petugas. Hal ini dikarenakan, dengan adanya kepatuhan maka tingkat risiko kesalahan dalam penanganan pasien dapat terminimalisir. 
Tabel 1 Karekteristik Responden

\begin{tabular}{lcc}
\hline Karakteristik & $\mathbf{f}$ & $\%$ \\
\hline Umur & & \\
$\quad$ Remaja akhir (17-25) & 3 & 14,29 \\
Dewasa Awal (26-35) & 10 & 47,61 \\
$\quad$ Dewasa Akhir (36-45) & 8 & 38,10 \\
Jenis Kelamin & & \\
$\quad$ Laki Laki & 15 & 71,43 \\
$\quad$ Perempuan & 6 & 28,57 \\
Pendidikan & & \\
$\quad$ D3 Keperawatan & 17 & 80,95 \\
$\quad$ Ners & 4 & 19,05 \\
Lama Kerja & & \\
< 3 Tahun & 7 & 33,33 \\
$\quad>3$ Tahun & 14 & 66,67 \\
Total & 21 & 100 \\
\hline
\end{tabular}

Berdasarkan Tabel 1 dapat diketahui karakteristik yang berbeda-beda yaitu dari 21 responden sebagian besar berjenis kelamin laki laki yaitu sebanyak 15 responden (71,43\%), sedangkan yang berjenis kelamin perempuan sebanyak 6 responden (28,57\%). Penelitian ini menunjukkan bahwa yang banyak bekerja di IGD adalah Laki-laki, maka membuktikan bahwa di IGD dibutuhkan tenaga laki laki karna lebih sigap, cepat dan Kuat dalam melaksanakan Triage. Umur responden sebagian berumur perawat berada pada usia 26-35 tahun yaitu sebanyak 10 responden (47,61\%), sedangkan umur paling sedikit yaitu umur 17-25 tahun sebanyak 3 responden (14,29\%). teori (7) dimana salah satu faktor yang mempengaruhi lama kerja adalah batasan usia produktivitas kerja. Perawat sebagai pemberi pelayanan kesehatan diharapkan dengan bertambahnya usia semakin matang seseorang semakin meningkat kemampuan seseorang dalam berfikir rasional dan kinerja akan meningkat.

Pendidikan sebagian besar responden berpendidikan D3 sebanyak 17 responden (80,95\%), dan 4 responden lainnya berpendidikan S1 (19,05\%). Pendidikan merupakan pengalaman yang berfungsi mengembangkan kemampuan dan kualitas seseorang, dimana semakin tinggi pendidikan seseorang maka semakin besar keinginan untuk memanfaatkan pengetahuan dan ketrampilannya. Selain pendidikan perawat juga diperlukan bersertifikat PPGD atau BTCLS. Lamanya bekerja di Ruang IGD sebagian besar responden baru bekerja selama lebih dari 3 tahun sebanyak 14 responden (66,67\%). Hal ini menunjukkan bahwa sebagian besar perawat yang bekerja di ruang IGD adalah pegawai lama. Hasil ini sejalan dengan penelitian Jazilahtul hosnaniah dengan hasil sebagian besar responden di Rumah Sakit Reksa Waluya Mojokerto sebagian besar bekerja selama lebih dari 5 tahun yaitu sebanyak 5 responden $(71,4 \%)(8)$. Lama bekerja akan berdampak pada kecakapan dan ketrampilan dalam pekerjaan terutama di ruang IGD.

\section{Tingkat Kepatuhan}

Tabel 2 Kepatuhan Responden

\begin{tabular}{lcc}
\hline Kepatuhan & $\mathbf{f}$ & $\%$ \\
\hline Patuh & 15 & 71,43 \\
Tidak patuh & 6 & 28,57 \\
\hline Total & 21 & 100 \\
\hline
\end{tabular}


Berdasarkan Tabel. 2 diketahui kepatuhan perawat dalam pelaksanaan SOP triage sebagian besar patuh. sebanyak 15 responden $(71,43 \%)$.

\section{Analisa Bivariat}

Tabel 3 Uji Fisher Exact Test

\begin{tabular}{llllll}
\hline \multirow{3}{*}{ kepatuhan } & \multicolumn{4}{c}{ Lama kerja } & \multirow{2}{*}{$\begin{array}{c}\mathbf{c} \\
\text { value }\end{array}$} \\
\cline { 2 - 5 } & \multicolumn{2}{c}{ baru } & \multicolumn{2}{c}{ Lama } & \\
\cline { 2 - 5 } & $\mathbf{f}$ & $\%$ & $\mathbf{f}$ & $\%$ & \\
\hline Patuh & 3 & 14.3 & 12 & 57,1 & 0,120 \\
Tidak Patuh & 4 & 19,0 & 2 & 9,5 & \\
\hline Total & $\mathbf{7}$ & $\mathbf{3 3 , 3}$ & $\mathbf{1 4}$ & $\mathbf{6 6 . 7}$ & \\
\hline
\end{tabular}

Sumber: Data Primer $201 \overline{7}$

Berdasarkan uji statistik Fisher Exact Test dengan sistem komputerisasi, didapatkan nilai p-value $=0,120(p>0,05)$. Sehingga dapat disimpulkan bahwa tidak ada hubungan yang signifikan antara lama kerja dengan kepatuhan pelaksanaan SOP triage. Ketidakpatuhan perawat dalam pelaksanaan SOP triage disebabkan oleh beberapa faktor. Faktor-faktor tersebut diantaranya adalah jumlah pasien, keterbatasan waktu, dan kebiasaan perawat. Salah satunya tentang pengkodean warna dan mendekatkan alat yang dibutuhkan dalam menangani pasien pada tempat yang terjangkau (dekat) dengan pasien.

Jumlah pasien yang yang harus ditangani dalam satu waktu yang menyebabkan perawat IGD kurang tepat dalam memberikan kode warna pada pasien. Ketidaktepatan tersebut mengakibatkan penanganan yang tidak sesuai, berdasarkan hal tersebut membuat perawat tidak patuh dalam pelaksanaan SOP triage yang ada. Keterbatasan waktu atau respon time dalam penanganan pasien menjadi faktor lain yang membuat perawat kurang patuh dalam pengambilan keputusan sedangkan pengambilan keputusan adalah hal terpenting.

Kebiasaan perawat tidak luput menjadi faktor yang mengakibatkan perawat kurang patuh dalam pelaksanaan SOP triage. Hal ini terbukti dengan tidak mestinya penggolongan pasien berdasarkan tingkat kegawatan. Perawat lebih terbiasa menangani pasien berdasarkan kedatangannya bukan berdasarkan resiko kecacatan maupun derajat kegawatan.

\section{SIMPULAN DAN SARAN}

Sebagian besar karakteristik responden berusia dewasa awal 26-35 tahun, Berpendidikan D3, berjenis kelamin laki - laki dan memiliki masa kerja diatas 3 tahun. Sebagian besar responden di IGD mempunyai tingkat kepatuhan dalam pelaksanaan SOP triage $(71,43 \%)$ dan yang tidak patuh 6 responden(28,6\%). Tidak terdapat hubungan yang signifikan antara lama kerja dengan kepatuhan dalam pelaksanaan SOP triage di IGD. 


\section{DAFTAR PUSTAKA}

1. Mathuridy, Roly Marwan. "Hubungan Umur, Lama Kerja, Pendidikan Dan Motivasi Dengan Kepatuhan Perawat Melakukan Enam Langkah Lima MomentCuci Tangan Di Ruang Icu Rsud Ulin Banjarmasin." Caring 2.1 (2015): 49-58.

2. Depkes, R. I. "Pedoman Penyelenggaraan dan Prosedur Rekam Medis Rumah Sakit di Indonesia." Revisi II. Direktorat Jenderal Bina Pelayanan Medik. Jakarta (2006).

3. Iriana, Ace Sudrajat Suhana Haeriyanto Pramita. "Hubungan Pengetahuan Dan Pengalaman Perawat Dengan Keterampilan Triase Pasien Di Igd Rscm." Jurnal Keperawatan 2.3 (2014): 118-129.

4. Rodyah, Silvi Anita Uslatu. "Hubungan Lingkungan Kerja Perawat Dengan Tingkat Kepatuhan Pelaksanaan 5 Momen Hand Hygiene Di Ruang Rawat Inap Rumah Sakit Umum Kaliwates Pt Rolas Nusantara Medika Jember." (2015)

5. Oman, Kathleen S., Jane Koziol-Mclain, And Linda J. Scheetz. "Panduan Belajar Keperawatan Emergensi." Egc, 2008.

6. Keputusan Direktur Rumah Sakit Umum Daerah Wates Nomor 18.1 Tahun 2015.

7. Swastha, Basu, And T. Hani Handoko. "Manajemen Sumber Daya Manusia, Edisi Ke Tiga." Penerbit Erlangga, Jakarta (2007).

8. Hosnaniah, Jazilahtul. "Pelaksanaan Triage Di Unit Gawat Darurat Rumah Sakit Reksa Waluya Kota Mojokerto." Kti D3 KEPERAWATAN (2014). 